\title{
SOLAR ASSISTED REFRIGERATING E- RICKSHAW SYSTEM USED FOR STREET VENDORS
}

\author{
Surender Kumar, R.S. Bharj \\ E-Mail Id: surender10161007@gmail.com, bharjrs@nitj.ac.in \\ Department of Mechanical Engineering Department, NIT, Jalandhar (PB), India
}

\begin{abstract}
Electric vehicles are widely used in urban cold chain logistic delivery. Temperature-sensitive logistics are more challenging for small order deliveries in terms of cost and time constraints. Sustainable development of cold chain logistics is essential in road transportation. The solar-assisted refrigerating E-rickshaw has been proposed in this study. The performance of this system was analyzed under different operating conditions. The impact of changing the load on maximum vehicle speed and trip distance was investigated. The solar panel produced an average of $3140 \mathrm{Wh}$ of solar energy in one sunny day. The vehicle was reached a maximum speed of $23 \mathrm{~km} / \mathrm{h}$ while carrying a $200 \mathrm{~kg}$ load. The vehicle covered a distance of $60.4 \mathrm{~km}$ with the battery bank alone at $200 \mathrm{~kg}$ load condition. It was traveling $63.4 \mathrm{~km}$ distance with hybrid energy mode. The solar panel extended the cruising range of the vehicle by 3.2 kilometers.
\end{abstract}

Keywords: E-mobility, energy consumption, performance, economic analysis.

\section{INTRODUCTION}

India is the world's second-largest producer of horticulture products. About $25 \%$ of perishable products are lost due to inadequate storage and cold chain (CC) transportation infrastructure. The per capita availability of fruits and vegetables is $20-30 \%$ of the total production. Modern perishable food distribution systems are a major source of environmental pollution in the CC [1].

The temperature-controlled refrigerating chamber fitted on the vehicles is needed in the current cold chain for food, medicine, fresh and perishable products transportation [2]. The $\mathrm{CC}$ is responsible for the safe delivery of highquality foodstuff to consumers. Most of the perishable produce requires a cooling temperature between 0 to $-15^{\circ} \mathrm{C}$ for safe storage and transportation purposes [3].

The cold chain logistics industry (CCLI) is under pressure to reduce product storage and delivery costs. If the product's delivery time increases due to any reason, the severe loss of foodstuff quality and food safety cannot be guaranteed. Perishable foodstuff transportation has become more expensive with the development of CCLI. The fresh foodstuff deterioration, higher urban area pollution, and continuous growth of fuel cost are still some hidden dangers in the CCLI [4].

With the awareness of people, these are choosing green and healthy foodstuff in the current time era. The fresh food demand is continuously increasing due to the increasing worldwide population. The government of developing countries is highly focusing on carbon emissions reduction in cold chain transportation to prevent a series of environmental threats [5]. Current cold chain vehicles consume $25 \%$ more fuel to preserve perishable goods at a suitable temperature.

More than $40 \%$ of food items require refrigerated vehicles during foodstuff delivery. Refrigeration is consuming $53 \%$ of the total power in different operations. The global cold chain logistics industry (GCCLI) was worth 160,000 million dollars in 2018. This industry is expected to grow to 585,000 million dollars by 2025. The CAGR of GCCLI is projected as $17.9 \%$ [6]. The GCCLI market is divided into five major categories: 1) fruits and vegetables, 2) medicines and pharmaceuticals, 3) meat and seafood, 4) milk products, and 5) bakery [7].

The development of carbon-free megacities is one of the prime goals of many governments all over the world. This target can be achieved globally by gradually reducing fossil fuels and promoting solar energy in GCCLI [8-9].

Refrigerated vehicles (RVs) are suitable for a wide range of deliveries from one city to another city. The ICE-based RVs are confronting some restrictions that available in the current market [10]. RVs used in the current market are neither very energy efficient or cost-effective for small-scale intercity goods deliveries. Therefore, the vehicle manufacturing industries are moving toward developing the latest refrigerating electric vehicle using the newest technologies and materials. This research paper focused on the performance analysis of a solar-assisted refrigerating E-rickshaw system.

\section{REVIEW ON SOLAR E- RICKSHAW SYSTEM}

The fast deterioration of environmental quality as a result of pollution concerns and the depletion of fossil fuels is driving the world to create alternative technologies such as solar hybrid rickshaws for cold chain logistics industry [11-12]. In the developing world, solar hybrid rickshaws have gained significant attention as a green and sustainable transportation alternative to traditional fossil fuel-powered load carrying vehicles. The past studies on solar Erickshaw system are reviews in table 2.1 . 


\section{International Journal of Technical Research \& Science}

\section{Table- 2.1 Review on Solar E- Rickshaw System}

\begin{tabular}{|c|c|c|}
\hline Author \& Year & $\begin{array}{c}\text { Type of solar panel \& motor } \\
\text { used }\end{array}$ & Type of rickshaw \& output parameters measured \\
\hline \multirow[t]{2}{*}{$\begin{array}{l}\text { Gurkaynak et } \\
\text { al., } 2009[13]\end{array}$} & $\begin{array}{l}\text { Poly-crystalline silicon } \\
\text { photovoltaic array; } \\
\text { BLDC motor. }\end{array}$ & $\begin{array}{l}\text { - Photovoltaic-battery operated electric auto rickshaw; } \\
\text { - PV array voltage and power; } \\
\text { - Vehicle driving distance range. }\end{array}$ \\
\hline & \multicolumn{2}{|c|}{$\begin{array}{l}\text { Short description: For the Indian market, a novel solar hybrid electric auto-rickshaw has been } \\
\text { proposed. This rickshaw's overall efficiency }(70.1 \%) \text { was higher than conventional auto- } \\
\text { rickshaw (19\%). }\end{array}$} \\
\hline \multirow[t]{2}{*}{$\begin{array}{l}\text { Mulhall, et al., } \\
2010[14]\end{array}$} & $\begin{array}{l}\text { Poly-crystalline silicon } \\
\text { photovoltaic array; } \\
\text { BLDC motor. }\end{array}$ & $\begin{array}{l}\text { - Solar-assisted electric auto rickshaw; } \\
\text { - Current and power consumption of motor; } \\
\text { - Distance covered by this rickshaw; } \\
\text { - Daytime and evening driving cycle. }\end{array}$ \\
\hline & \multicolumn{2}{|c|}{$\begin{array}{l}\text { Short description: This paper presents recent design studies, simulations (using ADVISOR } \\
\text { software), and experimental validation for a solar-assisted electric auto rickshaw. With an } \\
\text { integrated battery system, the Rickshaw's technological development goal was to reduce the } \\
\text { total electric power needed for propulsion. This rickshaw was covering } 90 \mathrm{~km} \text { in a hybrid mode } \\
\text { of energy. }\end{array}$} \\
\hline \multirow[t]{2}{*}{$\begin{array}{l}\text { Reddy \& } \\
\text { Sarma, } 2012 \\
\quad[15]\end{array}$} & $\begin{array}{l}\text { Mono-crystalline silicon } \\
\text { photovoltaic panel; } \\
\text { DC motor. }\end{array}$ & $\begin{array}{l}\text { - Solar-power assisted vehicle prototype; } \\
\text { - The power produced by solar panel; } \\
\text { - Distance covered by the vehicle. }\end{array}$ \\
\hline & \multicolumn{2}{|c|}{$\begin{array}{l}\text { Short description: A prototype of the electric vehicle was developed. The performance of the } \\
\text { electric vehicle was compared with the conventional car. }\end{array}$} \\
\hline \multirow[t]{2}{*}{$\begin{array}{l}\text { Siddique et al., } \\
2013[16]\end{array}$} & $\begin{array}{l}\text { Mono-crystalline silicon } \\
\text { type solar module; } \\
\text { DC-motor }(48 \mathrm{~V})\end{array}$ & $\begin{array}{l}\text { - Solar-power assisted ambulance; } \\
\text { - Battery current and voltage; } \\
\text { - PV current and voltage; } \\
\text { - Energy consumption of the DC motor. }\end{array}$ \\
\hline & \multicolumn{2}{|c|}{$\begin{array}{l}\text { Short description: The solar-powered rickshaw ambulance was designed for use in rural areas. } \\
\text { MATLAB (Simulink) was used to examine the solar panel's performance. The proposed model } \\
\text { was compared with other existing modes of transport system in the rural health sector. }\end{array}$} \\
\hline \multirow[t]{2}{*}{$\begin{array}{c}\text { Rhaman \& } \\
\text { Toshon, } 2014 \\
\text { [17] }\end{array}$} & $\begin{array}{l}\text { Four } 75 \mathrm{~W} \text { solar panels; } \\
\text { BLDC motor. }\end{array}$ & $\begin{array}{l}\text { - Solar-powered and pedal-assisted rickshaw; } \\
\text { - Motor speed variation with power consumption; } \\
\text { - PV current and voltage. }\end{array}$ \\
\hline & \multicolumn{2}{|c|}{$\begin{array}{l}\text { Short description: Solar Power Rickshaw was reducing the physical labor of the manually- } \\
\text { paddled rickshaw. This rickshaw was running at } 25 \mathrm{~km} \text { per hour that was faster than } \\
\text { conventional Rickshaws. }\end{array}$} \\
\hline \multirow[t]{2}{*}{$\begin{array}{l}\text { Sameeullah \& } \\
\text { Chandel, } 2016 \\
\quad[18]\end{array}$} & $\begin{array}{l}560 \mathrm{~W} \text { PV system; } \\
\text { BLDC motor. }\end{array}$ & $\begin{array}{l}\text { - Solar assisted hybrid electric rickshaw; } \\
\text { - Solar irradiance; } \\
\text { - The power output of the solar panel; } \\
\text { - Financial analysis of this vehicle. }\end{array}$ \\
\hline & \multicolumn{2}{|c|}{$\begin{array}{l}\text { Short description: The performance of this vehicle was analyzed by using Matlab and software. } \\
\text { The solar E-motor rickshaw was consuming } 42 \mathrm{Wh} / \mathrm{Km} \text { of energy and covered } 124 \text { kilometers. }\end{array}$} \\
\hline \multirow[t]{2}{*}{$\begin{array}{l}\text { Reddy et al., } \\
2017[19]\end{array}$} & $\begin{array}{l}\text { Two mono-crystalline solar } \\
\text { panels }(470 \mathrm{~W}) \text {; } \\
\text { BLDC motor }(48 \mathrm{~V})\end{array}$ & $\begin{array}{l}\text { - Solar-powered electric auto-rickshaw (SPEAR); } \\
\text { - Solar irradiance; } \\
\text { - The power output of the solar panel; } \\
\text { - Vehicle speed and battery discharge rate; } \\
\text { - Economic analysis of the vehicles. }\end{array}$ \\
\hline & \multicolumn{2}{|c|}{$\begin{array}{l}\text { Short description: With a battery discharge rate of } 296 \mathrm{~W} \text { at } 90 \mathrm{~kg} \text { load, the vehicle was reached } \\
\text { a top speed of } 21.69 \mathrm{~km} / \mathrm{h} \text {. With a maximum discharge rate of } 540 \mathrm{~W} \text { at } 390 \mathrm{~kg} \text { load, the vehicle } \\
\text { reached a top speed of } 12.11 \mathrm{~km} / \mathrm{h} \text {. }\end{array}$} \\
\hline $\begin{array}{c}\text { Karim \& } \\
\text { Shahid, } 2018 \\
{[20]}\end{array}$ & $\begin{array}{l}\text { Four solar panels; } \\
\text { BLDC motor. }\end{array}$ & $\begin{array}{l}\text { - Conventional petrol car converted into the solar-electric } \\
\text { hybrid car; } \\
\text { - Power consumed by the BLDC motor; } \\
\text { - Battery voltage; } \\
\text { - Distance covered by the vehicle. }\end{array}$ \\
\hline
\end{tabular}


† J $\mathrm{T}$ R International Journal of Technical Research \& Science

\begin{tabular}{|c|c|c|}
\hline & $\begin{array}{l}\text { bank was able to store } 5760 \mathrm{~V} \\
\text { lead-acid battery, which mear } \\
\text { motor of this vehicle was con }\end{array}$ & $\begin{array}{l}\text { h of energy. Maximum } 50 \% \text { energy can be drain-out from the } \\
\text { DC motor maximum energy was using } 2880 \mathrm{Wh} \text {. The BLDC } \\
\text { aming } 48 \mathrm{Wh} / \mathrm{km} \text {. }\end{array}$ \\
\hline \multirow[t]{2}{*}{$\begin{array}{l}\text { Waseem et al., } \\
2019 \text { [21] }\end{array}$} & $\begin{array}{l}\text { PV panels used; } \\
\text { BLDC motor. }\end{array}$ & $\begin{array}{l}\text { - Solar PV technology is integrated with electric and hybrid } \\
\text { vehicles. }\end{array}$ \\
\hline & \multicolumn{2}{|c|}{$\begin{array}{l}\text { Short description: The Indian transportation sector was demanding green-powered electric } \\
\text { vehicles. The use of solar PV technologies in battery, hybrid, and self-driving cars was } \\
\text { demonstrated. }\end{array}$} \\
\hline \multirow[t]{2}{*}{$\begin{array}{l}\text { Nambisan et al., } \\
2020 \text { [22] }\end{array}$} & $\begin{array}{l}\text { Two poly-crystalline silicon } \\
\text { photovoltaic; } \\
\text { BLDC motor. }\end{array}$ & $\begin{array}{l}\text { - Solar assisted battery and super-capacitor-based E-rickshaw; } \\
\text { - Motor power requirement; } \\
\text { - Economic analysis of the vehicle. }\end{array}$ \\
\hline & \multicolumn{2}{|c|}{$\begin{array}{l}\text { Short description: The E-rickshaw (solar-assisted battery and super capacitor-based) was } \\
\text { modeled and simulated in MATLAB. As compared to lead-acid batteries, the super-capacitor } \\
\text { has a lower environmental effect. The cycle life of the super-capacitor }(2.7 \mathrm{~V}, 350 \mathrm{~F} \text { ) was } \\
500,000 \text { cycles, and the cost was INR } 776.03 \text {. }\end{array}$} \\
\hline \multirow[t]{2}{*}{$\begin{array}{l}\text { Dhar et al., } \\
2021[23]\end{array}$} & $\begin{array}{l}\text { Test without solar panel; } \\
\text { BLDC motor. }\end{array}$ & $\begin{array}{l}\text { - E-auto rickshaw; } \\
\text { - Cost comparison of various motors; } \\
\text { - Cost comparison for EV and gas-powered auto-rickshaws; } \\
\text { - Torque-speed characteristics of BLDC motor. }\end{array}$ \\
\hline & \multicolumn{2}{|c|}{$\begin{array}{l}\text { Short description: Due to the continued growing fuel prices and stricter emission rules in } \\
\text { developing countries, the short-range transportation industry is shifting to EVs. BLDC motors } \\
\text { were potent and light, delivering constant power over a broad speed spectrum, making them } \\
\text { ideal for short-range transportation. }\end{array}$} \\
\hline
\end{tabular}

Some studies have already been done on solar electric rickshaw systems, but very limited work is done on integral system of solar refrigerated E-rickshaw. Previous research had several shortcomings in terms of integral system performance, energy savings, and economic analyses. Therefore, the present work focuses on the performance analysis of a solar-assisted refrigerating E-rickshaw system.

\section{TRACTIVE FORCE REQUIRED}

Tractive effort $\left(\mathrm{F}_{\text {tractive }}\right)$ is required to move this vehicle in the longitudinal direction. Tractive effort acting on this vehicle is shown in figure 3.1. The mathematical expression (Newton Second Laws of motion) between forces and acceleration in the longitudinal direction (X-direction) for the vehicle is shown by equation (1).

$F_{\text {tractive }}=\lambda M \frac{d V_{x}}{d t}+\sum F_{\text {resistive }}$

$F_{\text {tractive }}$ is the total tractive effort acting on the wheel of this vehicle in the $\mathrm{x}$-direction, $\mathrm{M}$ is the total mass of this vehicle, $\mathrm{dV}_{\mathrm{X}} / \mathrm{dt}$ is torque required to move this vehicle, or electric propulsion to overtake the resistive forces. The resistive forces acting on this vehicle in the $\mathrm{x}$-direction are presented in equation (2).

$\sum F_{\text {resistive }}=\underbrace{M g \sin \alpha}_{\text {grade }}+\underbrace{M g \mu_{r} \cos \alpha}_{\text {roll }}+\frac{1}{2} \underbrace{\rho A_{f} C_{D} V_{X}^{2}}_{\text {drag }}$

$\alpha$ is the road slope angle, $\mathrm{g}$ is the gravitational constant, $\mu_{\mathrm{r}}$ is the rolling coefficient of friction (between the contact point of tire and road), $\rho$ is the air density, $A_{f}$ is the front area of this vehicle, the $C_{D}$ is the air coefficient of drag and $\mathrm{V}_{\mathrm{X}}$ is the longitudinal velocity of this vehicle in the longitudinal direction. The tractive effort required for the vehicle is presented in equation (3).

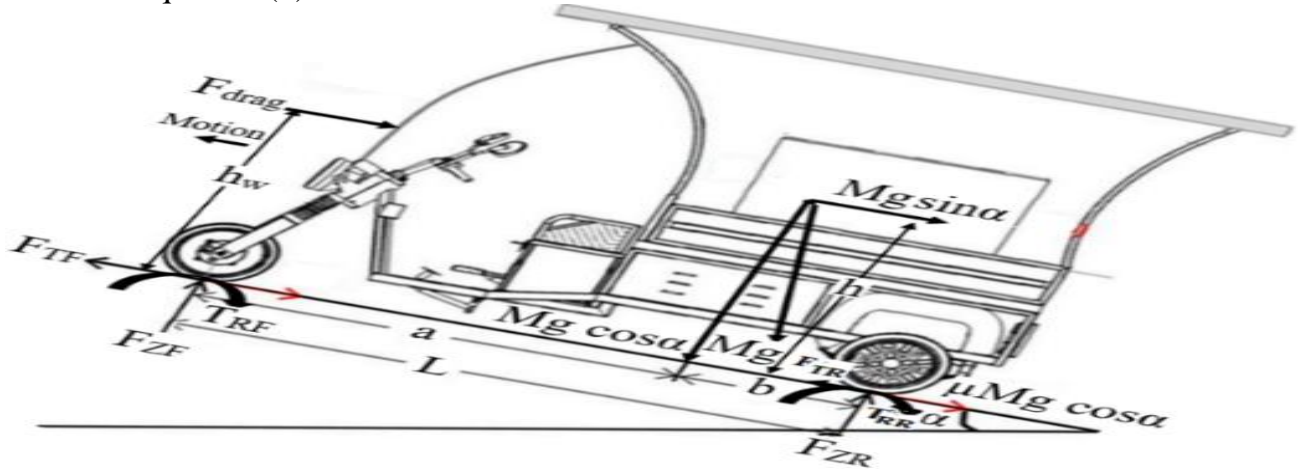

Fig. 3.1 Force acting on the solar refrigerating E-rickshaw

DOI Number: https://doi.org/10.30780/IJTRS.V06.I07.002

pg. 9

Paper Id: IJTRS-V6-I7-002

www.ijtrs.com, www.ijtrs.org 
\] T R S International Journal of Technical Research \& Science

Aerodynamic drag of solar refrigerating E-rickshaw $=\frac{1}{2} \rho C_{D} A V^{2}$

Air density @ $27{ }^{\mathrm{O}} \mathrm{C}=\rho=1.2\left(\mathrm{~kg} / \mathrm{m}^{3}\right)$

Vehicle frontal area or projected area $=\mathrm{A}(\mathrm{Sq} . \mathrm{m})=1249 \mathrm{~mm} \times 1768 \mathrm{~mm}=1.249 \times 1.768=2.21 \mathrm{~m}^{2}$

Drag coefficent $=\mathrm{C}_{\mathrm{D}}=0.45$

$1 \mathrm{kmph}=(1000 / 3600) \mathrm{m} / \mathrm{sec}=0.278 \mathrm{~m} / \mathrm{sec}$

At $5 \mathrm{kmph}$

$\operatorname{Drag}(\mathrm{N})=0.5 \times 1.2 \times 0.45 \times 2.21 \times(5 / 3.6)^{2}=1.153 \mathrm{~N}$

At $10 \mathrm{kmph}$

$\operatorname{Drag}(\mathrm{N})=0.5 \times 1.2 \times 0.45 \times 2.21 \times(10 / 3.6)^{2}=4.61 \mathrm{~N}$

At $15 \mathrm{kmph}$

$\operatorname{Drag}(\mathrm{N})=0.5 \times 1.2 \times 0.45 \times 2.21 \times(15 / 3.6)^{2}=10.375 \mathrm{~N}$

At $20 \mathrm{kmph}$

$\operatorname{Drag}(\mathrm{N})=0.5 \times 1.2 \times 0.45 \times 2.21 \times(20 / 3.6)^{2}=18.446 \mathrm{~N}$

At $25 \mathrm{kmph}$

$\operatorname{Drag}(\mathrm{N})=0.5 \times 1.2 \times 0.45 \times 2.21 \times(25 / 3.6)^{2}=\mathbf{2 8 . 8 2 2} \mathbf{N}$

Rolling resistance $=\mathbf{m} \times \mathbf{g} \times \boldsymbol{\mu} \times \cos \boldsymbol{\theta}$

Permissible load $(\mathrm{m})=(\mathrm{m}) \mathrm{kg}=460 \mathrm{~kg}$

Weight $=\mathrm{mg}\left(\right.$ newton or $\left.\mathrm{kg} \cdot \mathrm{m} / \mathrm{s}^{2}\right)$

Where $\mathrm{g}=9.80665 \mathrm{~m} / \mathrm{s}^{2}$

Rolling coefficent $(\mu)=0.015$

Rolling resistance at $\theta\left(12^{\circ}\right)=\mathrm{m} \times \mathrm{g} \times \mu \times \cos \theta=460 \times 9.80665 \times 0.015 \times \cos [12 \times(\pi / 180)]=\mathbf{6 7 . 6 6 5} \mathbf{N}$

Uphill resistance or climbing force $=\mathrm{mg} \sin \theta$

Permissible load $(\mathrm{m})=(\mathrm{m}) \mathrm{kg}=460 \mathrm{~kg}$

Where $\mathrm{g}=9.80665 \mathrm{~m} / \mathrm{s}^{2}$

Climbing force at $\theta\left(4^{\circ}\right)=m g \sin \theta=460 \times 9.81 \times \sin [4 \times(\pi / 180)]=5.496 \mathrm{~N}$

Climbing force at $\theta\left(8^{\circ}\right)=\mathrm{mg} \sin \theta=460 \times 9.81 \times \sin [8 \times(\pi / 180)]=10.99 \mathrm{~N}$

Climbing force at $\theta\left(12^{\circ}\right)=\mathrm{mg} \sin \theta=460 \times 9.81 \times \sin [12 \times(\pi / 180)]=\mathbf{1 6 . 4 8 6 9} \mathbf{N}$

\section{EXPERIMENTAL SETUP DESCRIPTION}

The experimental set-up consists of a refrigerator $(240 \mathrm{~L})$, solar energy production unit $(600 \mathrm{~W})$, solar charge controller (PWM), and battery bank (105 Ah). The refrigerator is fitted on the backside of this vehicle. Four PV panels are installed on the vehicle's roof to receive the maximum amount of solar radiation on sunny days. The MPPT solar charge controller is used to regulate the output solar energy fluctuation. The battery bank of this vehicle used four lead-acid batteries which are connected in series. The $48 \mathrm{~V}$ battery bank has a capacity of 105 Ah and is used for energy storage as well as powering the compressor and brushless direct-current (BLDC) motor. The battery power is converted into mechanical drive energy using an $850 \mathrm{~W}$ BLDC electric motor. The battery protection circuit regulates charge flow and prevents overcharging or deep drain of the battery bank. The vehicle's refrigerator is driven by a DC compressor (K35 DC ROHS Sol-cool). The refrigerator runs on a 12-12.6 V voltage range. A DC converter (48-12 V) is used to provide enough low voltage for the refrigerator. The low voltage disconnect (LVD) is used to regulate the refrigerator's energy fluctuations. The LVD shuts off the refrigerator's energy supply when the battery voltage reaches a critical level. The battery bank is charged at night using a simple mode power supply charger (SMPS-15 A). The block diagram and complete set-up of solar-assisted refrigerating E-rickshaw are shown in figures $3.1 \& 3.2$.

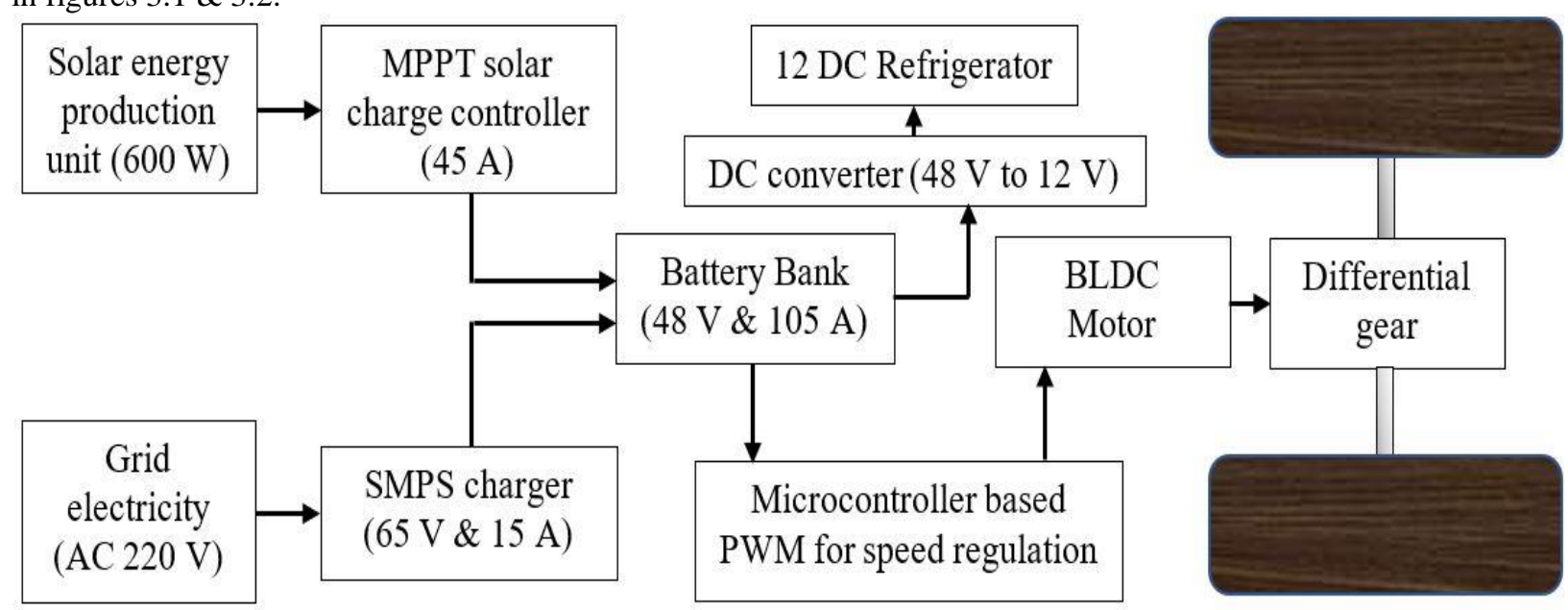

Fig. 4.1 Block diagram for solar-assisted refrigerating E-rikshaw

DOI Number: https://doi.org/10.30780/IJTRS.V06.I07.002

pg. 10

www.ijtrs.com, www.ijtrs.org

Paper Id: IJTRS-V6-I7-002

@ 2017, IJTRS All Right Reserved

Volume VI Issue VII, July 2021 


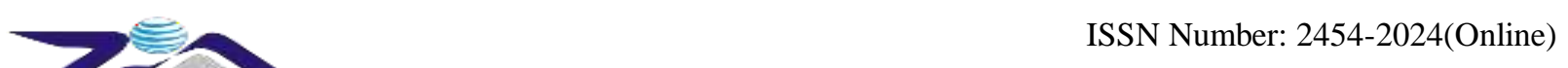

† J T R S International Journal of Technical Research \& Science

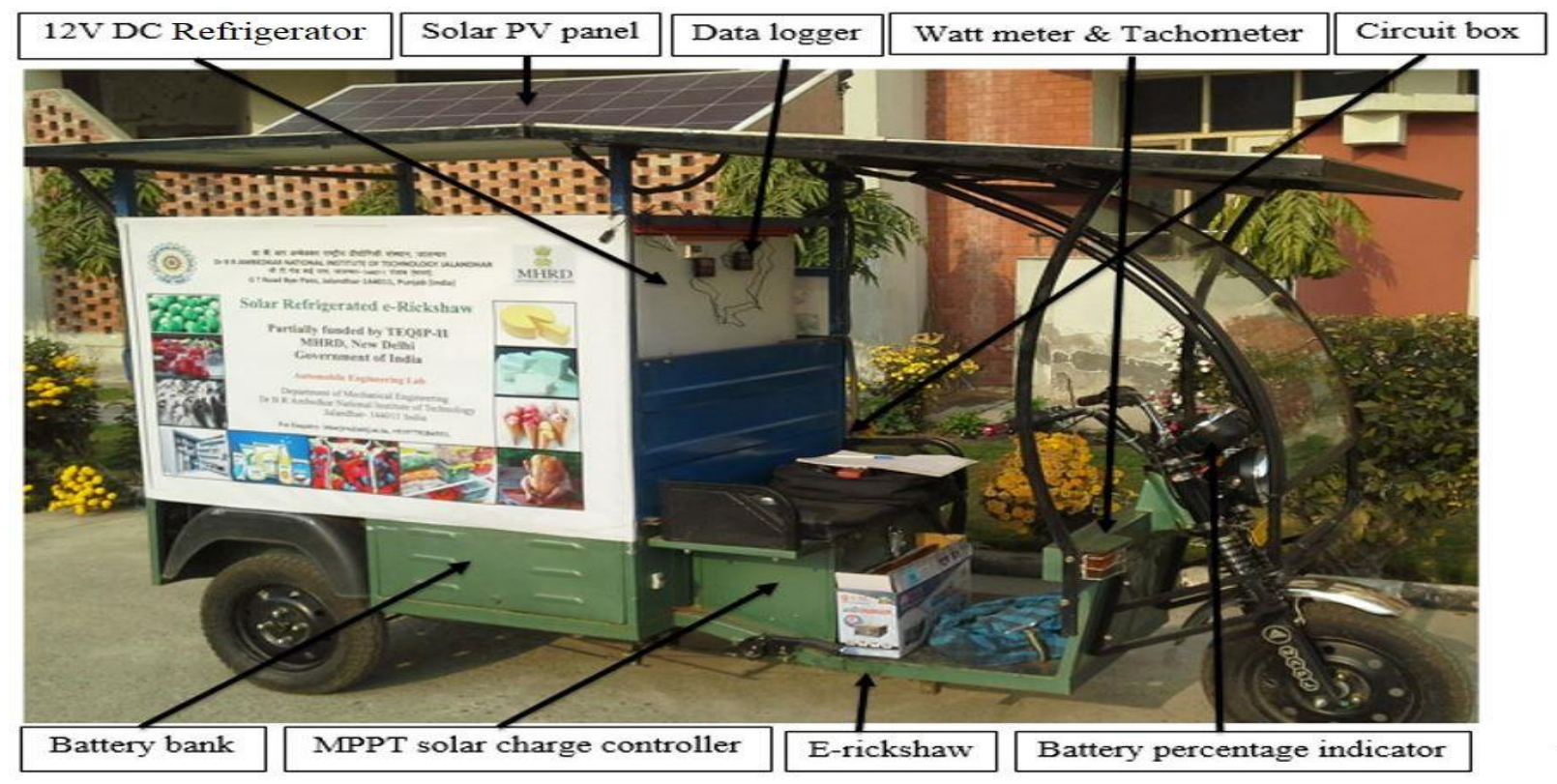

Fig. 4.2 Photographic view of solar-assisted refrigerating E-rikshaw

\section{PROCEDURE FOR PERFORMING EXPERIMENTS}

All the experiments were carried out at the National Institute of Technology's Department of Mechanical Engineering in Jalandhar, Punjab, India. These experiments were performed between 5th April to 26th May 2019 in the summer season. These experiments are performed with battery bank alone and the hybrid energy mode $(B+S)$. Two digital tachometers (NJK-5002C -Hitsan 4) proximity switch sensors are used to measure motor and vehicle speed. Three digital wattmeters (DC PZEM-051) are used to measure the output current of solar panels, input current of BLDC motor, and DC compressor. A solar pyranometer (Amprobe solar -100) is used to measure the solar radiation falling on the solar panel surface.

The following experimental conditions are maintained across this study:

$>$ The battery bank of the vehicle must be fully charged before starting each experiment.

$>$ The refrigerator chamber door is kept open for 8 hours to maintain thermal equilibrium with ambient air before starting each experiment.

$>$ The door of the refrigerator was kept closed during the experiment time.

$>$ The solar panels are always kept dust-free and have no shade on them throughout the day.

$>$ All these experiments are performed on the same location and same road route in sunny days conditions.

\section{RESULTS AND DISCUSSION}

The experiments are carried out to analyze the vehicle's performance on typical sunny days. These experiments are divided into three steps. The performance of PV panels is tested in the first step. The refrigerator of this vehicle is tested in the second phase by setting the thermostat position at 7th. The vehicle's performance is tested under various load situations in the third step.

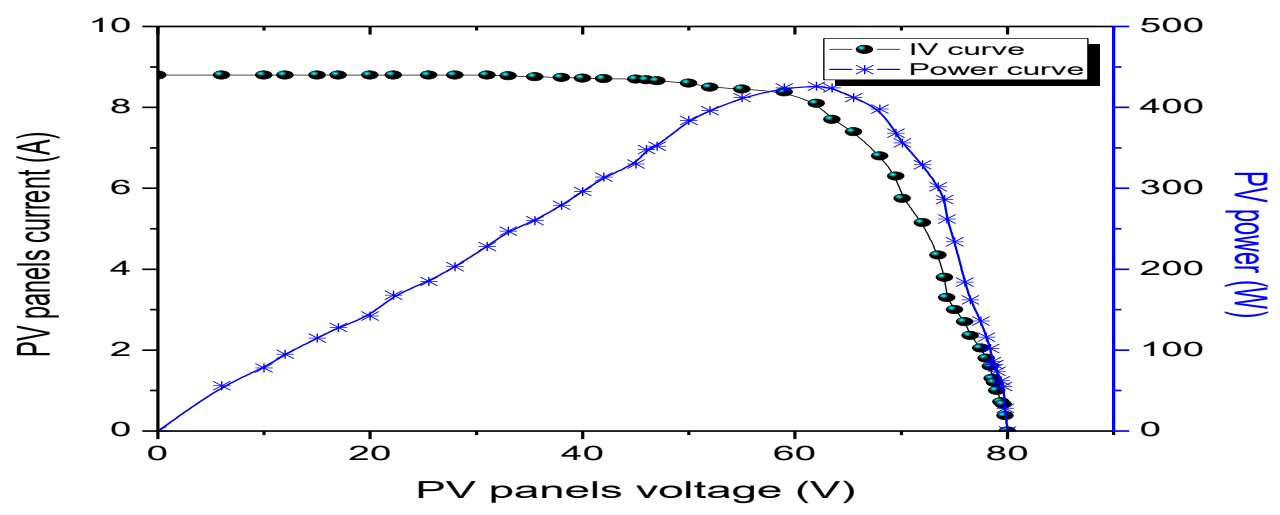

Fig. 6.1 PV panel performance 


\section{J T R S International Journal of Technical Research \& Science}

\subsection{Performance test of the PV Panel}

The performance of the PV panel on a typical day is shown in figure 6.1. The PV current, voltage, and power output vary in the range of 1.3-8.6 A, 10-62 V, and 55-425 W due to variations in solar irradiation on a typical sunny day. The solar energy generated yields $3.4 \mathrm{kWh}$ of energy on a sunny day.

\subsection{Experiment on the DC Refrigerator}

This experiment is carried out on a vehicle refrigerator with no load condition. The DC refrigerator's current and power consumption is shown in figure 6.2(a). The results show that the refrigerator consumed a maximum of $1.6 \mathrm{~A}$ current and $14.6 \mathrm{~W}$ power. The lower average temperature of $-14{ }^{\circ} \mathrm{C}$ was maintained inside the refrigerator chamber. The internal temperature variation of the refrigerated chamber is shown in figure $6.2(\mathrm{~b})$.

The voltage variation with the SOC of the vehicle battery bank is shown in figure 6.3. The higher voltage of $51.5 \mathrm{~V}$ was recorded for a fully charged battery bank. This vehicle battery bank's cutoff voltage was $46.5 \mathrm{~V}$. The distance traveled by a vehicle when the refrigerator is turned on position is shown in figure 6.4 . The vehicle covered $60.2 \mathrm{~km}$ with a load of $200 \mathrm{~kg}$ in 2.1 hours and consuming $1985 \mathrm{Wh}$ of energy when it runs only on the battery bank. This vehicle traveled $63.4 \mathrm{~km}$ in 2.2 hours with a $200 \mathrm{~kg}$ load and consuming $3450 \mathrm{Wh}$ of energy when operating in hybrid energy mode. This vehicle's acceleration and pickup time were decreased in hybrid mode.

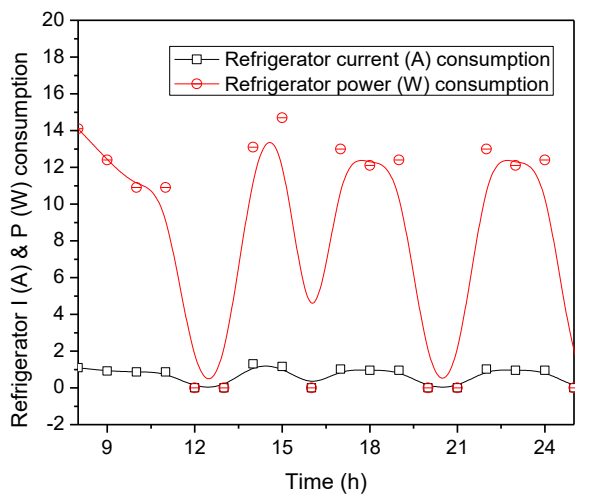

(a)

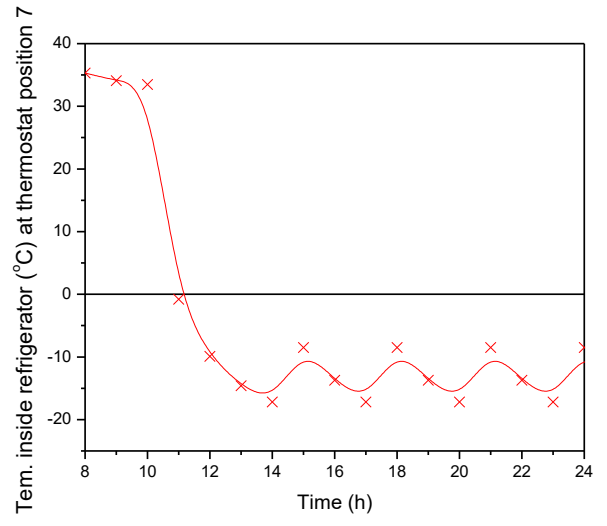

(b)

Fig. 6.2 Refrigerator (a) current and power consumption (b) chamber inside temperature variation

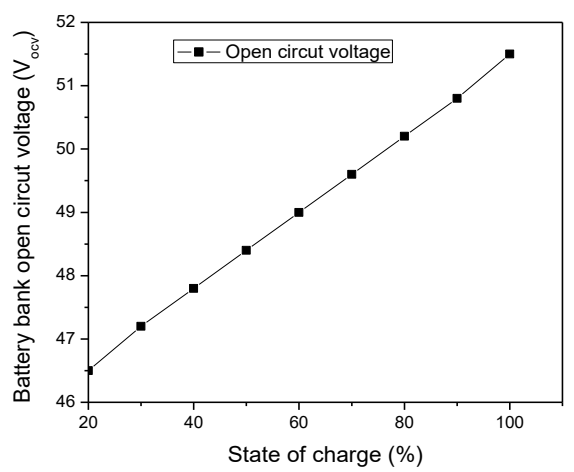

Fig. 6.3 The voltage variation with the state of charge (SOC)

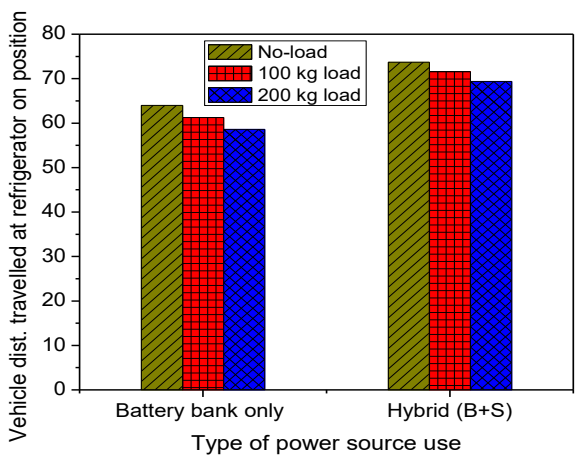

Fig. 6.4 The distance traveled by a vehicle when the refrigerator is turned on position 


\section{$7 \mathrm{~J}$ T S International Journal of Technical Research \& Science}

\subsection{Payback Period of Vehicle System with and Without Solar-Assistance}

The economic analysis and the payback period are calculated based on the Indian E-vehicle market study.

Case 1: Economic analysis and payback period for solar-assisted refrigerating electric vehicle

Vehicle's total cost $=\mathrm{A}$ (cost of vehicle) $+\mathrm{B}$ (cost of refrigerating unit) $+\mathrm{C}$ (cost of solar unit)

Total cost $=$ A $($ INR 140000.00 $)+B($ INR 65000.00 $)+$ C $($ INR 26000.00 $)=$ INR 231000.00

Solar energy generates by vehicle solar unit $=2-4 \mathrm{kWh}$ (depends on season)

Total solar energy generates by vehicle solar electricity unit per month $=$ Avg. solar unit $\times 30=3.5 \times 30=105 \mathrm{kWh}$

Average solar energy available in India 7-8 months per year

Average solar electricity unit generate per year $=105 \times 8=840 \mathrm{kWh}$

Single unit cost in Punjab state $=6$ INR

Average energy saved per year $=840 \times 6=5040 \mathrm{INR}$

Average reservation of this vehicle in a single day $=2-3$ booking

One time booking cost of vehicle $=250-450 \mathrm{INR}$

Total average cash earn by vehicle in single day $=$ Avg. booking in number $\times$ Avg. $\operatorname{cost}$ of booking $=2.5 \times 350$ $=875 \mathrm{INR}$

Cash earn by this vehicle per month $=875 \times 30=26250.00 \mathrm{INR}$

Cash earn by this vehicle per year $=26250 \times 12=315000.00 \mathrm{INR}$

Total money earns by this vehicle per year $=$ vehicle case earns per year + average energy saved per year $=315000$ $+5040=320040 \mathrm{INR}$

Payback period of this vehicle $=$ Total cost of refrigerated vehicle/Total money earns by this vehicle per year

Vehicle's payback period for solar-assisted refrigerating electric vehicle $=231000 / 320040=7.2$ months.

Case 2: Economic analysis and payback period for refrigerating electric vehicle without solar assistance.

Vehicle's total cost $=\mathrm{A}$ (cost of vehicle) $+\mathrm{B}$ (cost of refrigerating unit)

Total cost $=$ A $($ INR 140000.00$)+B($ INR 65000.00 $)=$ INR 205000.00

Average reservation of this vehicle in a single day $=2-3$ booking

One time booking cost of vehicle $=250-450 \mathrm{INR}$

Total average cash earn by vehicle in single day $=$ Avg. booking in number $\times$ Avg. cost of booking $=2.5 \times 350$ $=875 \mathrm{INR}$

Cash earn by this vehicle per month $=875 \times 30=26250.00 \mathrm{INR}$

Total cash earn by this vehicle per year $=26250 \times 12=315000.00 \mathrm{INR}$

Payback period of this vehicle $=$ Total cost of refrigerated vehicle/Total money earns by this vehicle per year Vehicle's payback period for refrigerating electric vehicle without solar assistance $=205000 / 315000=6.5$ months.

\section{CONCLUSION}

The solar-assisted refrigerating E-rikshaw was constructed for street vendors that are facing the sustainability problem for perishable foodstuff delivery in the CCLI. The vehicle's dimensions are L (2866 mm), W (1249 mm), and $\mathrm{H}(1768 \mathrm{~mm})$. The performance and energy consumption of this vehicle was studied under different load conditions. This vehicle battery was charged during the day using solar energy and at night with grid electricity.

The following are the key conclusions from the experiments:

$>$ Charging the battery bank with grid electricity required $9.5 \mathrm{kWh}$ of energy and 8-11 hours.

$>$ This vehicle battery bank's energy storage capacity was $5040 \mathrm{Wh}$.

$>$ The solar energy production unit was produced an average of $3140 \mathrm{Wh}$ of solar energy in one sunny day.

$>$ The battery bank of vehicle was fully charged in 1.6 days using solar energy.

$>$ The vehicle's cruising range was enhanced by 3.2 kilometers after using solar energy.

$>$ The vehicle's refrigerator consumed $98 \mathrm{Wh}$ of energy in one day while maintaining a temperature of $-17{ }^{\circ} \mathrm{C}$

$>$ The vehicle was travel at $23 \mathrm{~km} / \mathrm{h}$ speed with a $200 \mathrm{~kg}$ load.

$>$ The per-kilometer cost of the vehicle was 1-1.5 INR.

$>$ The vehicle payback period was 7.2 months and 6.5 months, respectively, with and without a solar producing system.

$>$ The vehicle travelled 63.4 kilometers in hybrid energy mode with a load of $200 \mathrm{~kg}$.

$>$ The vehicle's overall performance was improved, while acceleration time was decreased in hybrid energy mode.

This vehicle's operating and maintenance costs were low, making it ideal for street vendors delivering perishable foodstuffs.

\section{REFERENCES}

[1] Kondal, K. (2014), "Performance of Horticulture sector in India", International Journal of Scientific 
7 J T R S International Journal of Technical Research \& Science

Research, 3 (5) pp. 1-5.

[2] Badia-Melis, R., Ruiz-Garcia, L., Garcia-Hierro, J., \& Villalba, J. I. R. (2015), "Refrigerated fruit storage monitoring combining two different wireless sensing technologies: RFID and WSN", Sensors, 15 (3), pp. 4781 4795.

[3] Mercier, S., Villeneuve, S., Mondor, M., \& Uysal, I. (2017), "Time-temperature management along the food cold chain: A review of recent developments", Comprehensive Reviews in Food Science and Food Safety, 16(4), pp. 647-667.

[4] Li, Y., Lim, M. K., \& Tseng, M. L. (2019), “A green vehicle routing model based on modified particle swarm optimization for cold chain logistics", Industrial Management \& Data Systems.

[5] Prabhu, V., Gupta, S. K., Madhwal, S., \& Shridhar, V. (2019), "Exposure to atmospheric particulates and associated respirable deposition dose to street vendors at the residential and commercial sites in Dehradun City", Safety and health at work, 10 (2), pp. 237-244.

[6] Allied Market Research, 2019. Global Cold Chain Logistics Market: Opportunities and Forecast 2019-2026. Accessed on 25th may 2021).

[7] Liu, G., Hu, J., Yang, Y., Xia, S., \& Lim, M. K. (2020), "Vehicle routing problem in cold Chain logistics: A joint distribution model with carbon trading mechanisms. Resources", Conservation and Recycling, 156, p. 104715.

[8] Zhang, R., \& Hanaoka, T. (2021), "Deployment of electric vehicles in China to meet the carbon neutral target by 2060: Provincial disparities in energy systems, $\mathrm{CO}_{2}$ emissions, and cost effectiveness", Resources, Conservation and Recycling, 170, p. 105622.

[9] Bach, H., Makitie, T., Hansen, T., \& Steen, M. (2021), "Blending new and old in sustainability transitions: Technological alignment between fossil fuels and biofuels in Norwegian coastal shipping", Energy Research \& Social Science, 74, p. 101957.

[10] Kumar, S \& Bharj, R. (2021), "Experimental analysis of solar assisted refrigerating electric vehicle", International Journal of Engineering and Advance Technology, 10 (4), pp. 52-58.

[11] Ikram, H., Javed, A., Mehmood, M., Shah, M., Ali, M., \& Waqas, A. (2021), "Techno-economic evaluation of a solar PV integrated refrigeration system for a cold storage facility", Sustainable Energy Technologies and Assessments, 44, p. 101063.

[12] Gao, Y., Ji, J., Han, K., \& Zhang, F. (2021), "Comparative analysis on performance of PV direct-driven refrigeration system under two control methods", International Journal of Refrigeration, 127, pp. 21-33.

[13] Gurkaynak, Y., Onar, O., \& Khaligh, A. (2009), “A photovoltaic-battery powered all-electric rickshaw for the Indian market (No. 2009-01-1306). SAE Technical Paper.

[14] Mulhall, P., Lukic, S. M., Wirasingha, S. G., Lee, Y. J., \& Emadi, A. (2010), "Solar-assisted electric auto rickshaw three-wheeler", IEEE transactions on vehicular technology, 59(5), pp. 2298-2307.

[15] Reddy, N. N., \& Sarma, D. P. (2012), "Solar powered vehicle", International Journal of Advanced Research in Computer Science and Electronics Engineering (IJARCSEE), 1, pp. 36-39.

[16] Siddique, A. R. M., Zafar, N. B., Rahman, S. S., \& Kaiser, S. (2013), "Solar-based rickshaw ambulance for the remote areas of developing countries", In 2013 1st International Conference on Artificial Intelligence, Modelling and Simulation (pp. 381-384). IEEE.

[17] Rhaman, M., \& Toshon, T. A. (2014), "Solar powered rickshaw (SPR) can diminish the physical labor of rickshaw puller and improve the power crisis in Bangladesh", International Journal of Engineering and Manufacturing, 4(4), pp. 26-35.

[18] Sameeullah, M., \& Chandel, S. (2016, April). Design and analysis of solar electric rickshaw: A green transport model", In 2016 International Conference on Energy Efficient Technologies for Sustainability (ICEETS) (pp. 206-211). IEEE.

[19] Reddy, K. S., Aravindhan, S., \& Mallick, T. K. (2017), "Techno-economic investigation of solar powered electric auto-rickshaw for a sustainable transport system", Energies, 10(6), 754.

[20] Karim, A., \& Shahid, Z. (2018), "Performance and cost analysis of conventional petrol car converted into solarelectric hybrid car”, Journal of Energy Resources Technology, 140(3).

[21] Waseem, M., Sherwani, A. F., \& Suhaib, M. (2019), "Integration of solar energy in electrical, hybrid, autonomous vehicles: a technological review", SN Applied Sciences, 1(11), pp. 1-14.

[22] Nambisan, P., Bansal, S., \& Khanra, M. (2020), "Economic Performance of Solar Assisted Battery and Supercapacitor based E-Rickshaw”, In 2020 IEEE International Conference on Power Electronics, Smart Grid and Renewable Energy (PESGRE2020) (pp. 1-6). IEEE.

[23] Dhar, S., Jayakumar, A., Lavanya, R., \& Kumar, M. D. (2021), "Techno-economic assessment of various motors for three-wheeler E-auto rickshaw: From Indian context”, Materials Today: Proceedings. 